Journal of Agriculture and Social Research (JASR) Vol. 8, No. 2, 2008

\title{
EFFECTS OF ADOPTION OF IMPROVED VARIETIES OF CASSAVA STEM ON INCOME IN CASSAVA-BASED FARM HOLDINGS IN DELTA STATE, NIGERIA
}

\author{
T.G. APATA * OGUNYINKA A. I. ** AND O.M. APATA *** \\ *Department of Agricultural Economics and Extension Services, \\ Joseph Ayodele Babalola University (JABU) Ikeji-Arakeji, Osun State. \\ Corresponding Author's E-mail dayoapata@yahoo.com. \\ **Department of Agricultural Extension and Management, Federal College of Agriculture \\ Akure, Ondo State. E-mail idowuolaitan@yahoo.com \\ ***Department of Agricultural Economics and Extension Services, \\ University of Ado-Ekiti, Ekiti State. E-mail simboapata@yahoo.com
}

\begin{abstract}
The study examines the adoption of improved varieties of cassava on income generation and factors that influence adoption process. Purposive sampling was used in the collection of primary data. Ten local Government Areas (LGAs) were identified as major cassava growers in the state out of which 4 LGAs were randomly selected. Questionnaire was used to obtain data from 370 cassava growers. However, 350 observations were found useful for subsequent analysis. The result of the finding shows that awareness level of improved varieties was high $(88.6 \%)$ while $250(80.7 \%)$ respondents adopted the improved varieties. Farmers that adopted the improved varieties received revenue of \$46330 higher than non-adopters. Cassava growers adoption score, education, access to marketing facilities and extension facilities identified as factors influencing higher income and facilitates adoption process. Hence, increase use of these factors can facilitate adoption process and enhanced increase income.
\end{abstract}

Key words: Adoption; Cassava improved varieties, Cassava growers,

\section{INTRODUCTION}

Cassava is one of the major crops grown for food in Nigeria. It is the most widely cultivated crop in terms of area planted and the total number of farmers involved in its cultivation. Almost every household grows cassava and it serves both for food and major source of income (Nweke, 2003 and Manyong et al; 2005). Nigeria remains the world leader in cassava production since 1990 (IFAD/FAO 2005). The total land area under cassava cultivation in Nigeria is about 41.215 million hectares (Manyong et al, 2005). The annual production ranging from 30-40 million metric tones. This production outputs are in the hands of small-scale farmers who cultivated between 0.5-5 hectares. Cassava is used almost exclusively for consumption as $95 \%$ of the total cassava outputs produced were used as food (Ikpi and Natalie, 1989). This according to Nweke and Manyong (2000) has led to low returns and decline in local production of cassava primarily due to poor yield varieties of the cassava stem planted. In an effort to reverse this trend and salvaging the fortune of cassava growers, the Collaborative Study of Cassava in Africa (COSCA) under the supervision of International Institute of Tropical Agriculture (IITA) launched an aggressive mass mobilization campaign on improved varieties of cassava stem in the late 1980s (Nweke et al, 1996).

This technology has been disseminated to cassava farmers in Nigeria for adoption. Study carried out by Nweke and Manyong (2000) revealed that cassava farming has been transformed from being a staple food to a source of income as well. Among cassava growing households, this has contributed about $20 \%$ to household income, the study concluded.

Some studies have been carried out to investigate factors related to adoption of improved cassava varieties in Nigeria (Ezedinma, 1989; Akoroda et al, 1989, Neste, 1993; Nweke et al, 1996, Tewe and Bonkanga, 2001 and Nweke, 2003). How these factors that influence the 


\section{Journal of Agriculture and Social Research (JASR) Vol. 8, No. 2, 2008}

adoption of improved varieties of cassava stem and its impact on income generation has not been successfully investigated. Hence, there identified a research gap in the literature on adoption of improved varieties of cassava stem on income generation. Whether the adoption of improved cassava stem has a significant influence on income and also, what are the factors that can influence adoption process

Consequently, this study was carried out to assess the adoption of improved varieties of cassava stem on income generation. The specific objectives include to; determine the level of awareness and adoption process of the new improved cassava stem; assess the adoption of improved varieties of cassava stem on income generation of cassava growers; identify the factors influencing higher income as a result of adoption of the improved cassava stem.

The move to optimize cassava output potential of the country is seemingly increasing and government on the other hand is doing everything possible to make it work. In addition, government is creating necessary infrastructures to facilitate this. Hence, there is a need to literally make these improved varieties of cassava stem accessible and adopted among the cassava grower. Also, those factors that can facilitate its adoption process need to be investigated, which informed the purpose of the study.

\section{METHODOLOGY}

\section{Sampling Procedure}

Purposive sampling procedure was used in the collection of primary data needed for this study. Ten out 23 local Government Areas (LGAs) of Delta state were identified as major LGAs for cassava farming. Four LGAS were then randomly selected. Questionnaire was used to obtain data from 370 cassava growers across these 4 LGAs. However, 350 observations were found useful for subsequent analysis. Data were subjected to descriptive analysis, budgetary techniques and Logit model.

\section{Method of Data Analysis.}

In achieving objective 1, that is to determine the level of awareness and adoption process of the new improved cassava stem. The package approach of the use of adoption index used for this study burrows from the work of Daramola (1987) and Rahji (2005). This adoption index quantifies the adoption level of the recommendation practices of the innovation used by the respondent. The contributions of each component to output were measure and then rank accordingly. The ranking are then use to categorize adopters from non-adopters respectively.

For objective 2, to look at the revenue generated from adopting improved varieties of cassava stem. Budgetary analysis technique was adopted. This was use to assess adopting improved varieties of cassava stem on income generation

Budgetary analysis is explicitly stated as $\mathrm{NRi}=\sum \mathrm{PiQij}-\mathrm{Ci}$

Where NRi $=$ Net Revenue of Household $i$

$\mathrm{Pi}=$ The market price of inputs used

$\mathrm{Qi}=$ Outputs

$\mathrm{Ci}=$ Cost of input used. $\quad \mathrm{i}=1,2, \ldots, 350$

For objective 3 , to identify factors influencing higher income as a result of adoption process. The idea is to investigate those factors that can influence adoption process for enhanced income generation. In categorizing the cassava grower into adopters and non-adopters of improved varieties a threshold concept was used (Daramola, 1987). This was used to divide the grower of cassava into two (adopters and non-adopters). The common modeling used in this threshold concept include Probit, Logit and Tobit (Nassimbeni, 2001). 


\section{Journal of Agriculture and Social Research (JASR) Vol. 8, No. 2, 2008}

Logit model is preferred and adopted for this study because of easy computation of the dichotomy value involved. In addition, this model showcasing factors influencing this value (Herath and Takeya, 2003)

The basic logit model is given as:

$\operatorname{Pi}(\mathrm{Ai}=0) \quad=\frac{1}{\mathrm{I}+\mathrm{e}^{\mathrm{yi}}}$

The estimating logarithmic equation is given as

Yi $\quad=\beta o+\beta_{1} \ln _{1} X_{1}+\beta_{2} \operatorname{In}_{2} X_{2}, \ldots,+\beta_{11} \ln _{11} X_{11}$

Where Yi (the dummy variable) is the linear combination of the explanatory variable of interest $\mathrm{Yi}$ is $\mathrm{Ai}=1$ if adopter

$\mathrm{Ai}=0$ if non-adopter

$\beta o=$ constant term

$\beta_{1}-\beta_{11}=$ coefficients

$\mathrm{X}_{1}-\mathrm{X}_{11}=$ Explanatory variable.

The following explanatory variables are hypothesized to be factors influencing higher income as a result of adoption process of improved cassava stem. This burrows from the works of Herath and Takeya (2003). They are Cassava growers adoption score $\left(\mathrm{X}_{1}\right)$, Household size $\left(\mathrm{X}_{2}\right)$, Educational level $\left(\mathrm{X}_{3}\right)$, Age $\left(\mathrm{X}_{4}\right)$, Years in cassava farming $\left(\mathrm{X}_{5}\right)$, Profit/loss revenue derived from cassava farming $\left(\mathrm{X}_{6}\right)$, Farm size $\left(\mathrm{X}_{7}\right)$, Income from other Enterprise apart from cassava $\left(\mathrm{X}_{8}\right)$, Access to Extension facilities $\left(\mathrm{X}_{9}\right), \mathrm{D}=1$ if access $\mathrm{D}=0$ other wise, Access to market facilities $\left(\mathrm{X}_{10}\right), \mathrm{D}=1$ if access $\mathrm{D}=0$ other wise, access to credit $\left(\mathrm{X}_{11}\right), \mathrm{D}=1$ if access $\mathrm{D}=0$ other wise.

\section{RESULTS AND DISCUSSIONS}

Adoption is essentially a dynamic process that involves learning about the new technology over time (Cameron, 1999). It is a decision to continue use of an innovation over a reasonable long period of time (Idachaba, 1989). This process is in stages and it starts from the presence of a new idea / innovation, which the people must know about and learn to use or adopt.

In determining the level of awareness and adoption process for objective one. The contextual framework of adoption process of improved varieties / technology used in this study is adopted from Ikpi and Natali (1989) and is presented in Table 1

Table 1: Distribution of Respondents by Status of Adoption and Percentage of Adoption.

\begin{tabular}{|l|l|l|l|}
\hline S/N & Item & $\begin{array}{l}\text { No } \\
\text { Adopters }\end{array}$ & of \\
\hline 1 & Used improved cassava stem & 250 & 100.0 \\
2 & Spacing recommended by IITA Researchers & 210 & 84.0 \\
3 & Recommended time of planning & 185 & 74.0 \\
4 & Weeding at least 2 times before harvest & 172 & 68.0 \\
5 & Application of inorganic Fertilizer & 105 & 42.0 \\
6 & Planting data & 60 & 24.0 \\
\hline
\end{tabular}

Source: Field Survey, 2006

The above items were ranked according to their relative contributions to outputs. The ranking are thus used to develop adoption index. Following Daramola (1987) and Rahji (2005), the farmer becomes an adopter if he scores $40 \%$ and above of the rankings, hence, the adoption index is equal to one. A farmer becomes a non-adapter if he scores below $40 \%$ of the threshold concept; hence, the adoption index is equals to zero.

The data revealed 250 adopters and 100 non-adopters. Results from table 1 indicates that all the 250 adopters used improved cassava stems, $84.0 \%$ follow spacing techniques recommended by IITA consultants, $74 \%$ plant at the appropriate time, while $68.8 \%$ of the 


\section{Journal of Agriculture and Social Research (JASR) Vol. 8, No. 2, 2008}

respondents weeds at least 2 times before harvest as recommended. In addition to this, $42.0 \%$ applied inorganic fertilizers and $24.0 \%$ of the adopters used planting data.

There is thus a need to investigate whether cassava growers have access to information on the new improved varieties of cassava. The result of the finding reveals that $88.6 \%$ of the produces are aware of this technology, while $80.7 \%$ of the respondents used the improved varieties (Table 2). This represents $71.4 \%$ of the over-all respondents. This results thus, indicated that majority of the cassava growers are aware of the improved varieties. However, there is a need for further study to investigate the difference of the 60 respondents that did not adopt the improved varieties despite having knowledge about it.

The correlation analysis carried out between level of awareness and adoption process is presented in Table 2.

Table 2: Level of Awareness and Adoption Process Among the Respondents

\begin{tabular}{|l|c|c|}
\hline Item & $\mathrm{N}=350$ & Percentages $(\%)$ \\
\hline Awareness & 310 & 88.6 \\
\hline Adoption & 250 & $71.4^{*}$ \\
\hline $\mathrm{X}^{2} \mathrm{c}$ & $12.633(\mathrm{P}<0.05)$ & $\mathrm{X}^{2}{ }_{\mathrm{T}}=12.517$ \\
\hline
\end{tabular}

Source: Field Survey

* $80.7 \%$ of the population adopted the technology $(\mathrm{N}=250)$

Level of awareness is measured in terms of cassava growers contact with extension facilities, such as contact with extension agent, friends / relations that know about the technology, and or through Radio / TV., / Newspaper / Bulletin. The results revealed that there is a significant relationship between contact with extension facilities and adoption process at $5 \%$ level of Significance (Table 2). These results indicated that the more the cassava growers have access to extension facilities the higher the adoption. Thus confirmed that there is a significant relationship between level of awareness and adoption.

The results of the budgetary analysis used for the two groups (that is the adopters and nonadopters) are presented in Table 3 . For the adopters the mean profit is

$\$ 63,005.00$ as against the non-adopters of $16,675.00$. With regard to this measures, the results indicated that adoption of the improved varieties of cassava stem thus have positive influence on income generation of the growers.

Table 3: Revenues generated between Adopters and Non-Adopters.

\begin{tabular}{|l|lr|l|}
\hline & Items & \multicolumn{1}{|c|}{ Adopters } & Non-Adopters \\
\hline 1 & Benefits & (B) Mean Income & $148,325: 00$ \\
2 & Costs & (C) & $95,825: 00$ \\
& (i) Expenditures Inured in farm inputs & $85,320: 00$ & $79,150: 00$ \\
\hline & Mean Profit & $63,005: 00$ & $16,675: 00$ \\
\hline
\end{tabular}

Source: Field Survey, 2006

Explaining the factors influencing adoption process of the new improved cassava

stem and socio-economic variables on income. The results in Table 4 shows that growers adoption score $\left(\mathrm{X}_{1}\right)$ educational level $\left(\mathrm{X}_{3}\right)$, access to extension facilities $\left(\mathrm{X}_{9}\right)$ and access to market facilities $\left(\mathrm{X}_{10}\right)$. In addition to this, other sources of farm income $\left(\mathrm{X}_{8}\right)$ and access to credit $\left(\mathrm{X}_{11}\right)$ are explanatory variables identified as the factor influencing income as a result of adoption process.

On the basis of these facts cassava growers adoption score $\left(\mathrm{X}_{1}\right)$, educational level $\left(\mathrm{X}_{3}\right)$ and access to market $\left(\mathrm{X}_{10}\right)$ have positive significant influence income as a result of adoption process at 5\% level. On the other hand access to extension facilities $\left(\mathrm{X}_{9}\right)$ at $1 \%$ level of significant influence positively on adoption process. Other sources of farm income $\left(\mathrm{X}_{8}\right)$ and access to credit $\left(\mathrm{X}_{11}\right)$ have negative and significant influence on adoption process at $1 \%$ level. 


\section{Journal of Agriculture and Social Research (JASR) Vol. 8, No. 2, 2008}

Table 4 Result of the Logit Models

\begin{tabular}{|l|c|l|l|}
\hline Variable & Estimates (Std error) & Z. Value & $\mathrm{P}>1 \mathrm{z} 1$ \\
\hline Growers Adoption Score $\left(\mathrm{X}_{1}\right)^{1}$ & $0.8293(0.3113)$ & 2.66 & $0.005^{* *}$ \\
Household size $\left(\mathrm{X}_{2}\right)$ & $-1.8135(1.1825)$ & 1.53 & 0.183 \\
Educational level $\left(\mathrm{X}_{3}\right)$ & $0.6384(0.2719)$ & 2.34 & $0.005^{* *}$ \\
Age $\left(\mathrm{X}_{4}\right)$ & $0.0318(0.7612)$ & 0.04 & 0.818 \\
Farming experience $\left(\mathrm{X}_{5}\right)$ & $0.5316(0.5013)$ & 1.06 & 0.219 \\
Revenue from cassava farms $\left(\mathrm{X}_{6}\right)$ & $0.9215(0.7632)$ & 1.21 & 0.482 \\
Farm size $\left(\mathrm{X}_{7}\right)$ & $-0.5538(0.6132)$ & -0.90 & 0.358 \\
Other sources of farm income $\left(\mathrm{X}_{8}\right)$ & $-0.5186(0.1738)$ & -2.98 & $0.003^{*}$ \\
Access to extension facilities $\left(\mathrm{X}_{9}\right)$ & $0.4315(0.1381)$ & 3.12 & $0.002^{*}$ \\
Access to market facilities $\left(\mathrm{X}_{10}\right)$ & $0.6153(0.2815)$ & 2.18 & $0.008^{* * *}$ \\
Access to credit facilities $\left(\mathrm{X}_{11}\right)$ & $-0.3182(0.1156)$ & -2.75 & $0.003^{*}$ \\
\hline
\end{tabular}

Source: Logit model analysis computer results

$* *$ Significant at $1 \%, * * *$ Significant at $10 \%, *$ Significant at $5 \%$

Log likelihood -126.86

Table 5: Cassava Growers Mean Adoption Score and Mean Adoption Index.

\begin{tabular}{|l|l|l|l|l|}
\hline S/N & Item & $\begin{array}{l}\text { Adoption } \\
\text { Score }\end{array}$ & $\begin{array}{l}\text { Mean } \\
\text { Growers' } \\
\text { Adoption } \\
\text { score }\end{array}$ & $\begin{array}{l}\text { Mean } \\
\text { Growers' } \\
\text { Adoption } \\
\text { Index }\end{array}$ \\
\hline 1 & Used of improved cassava stem & 20 & 20 & 1.00 \\
2 & Spacing recommended by IITA Researchers & 15 & 8 & 0.53 \\
3 & Recommended time of planning & 13 & 5 & 0.39 \\
4 & Weeding at least 2 times before harvest & 10 & 7 & 0.70 \\
5 & Application of inorganic Fertilizer & 8 & 2 & 0.25 \\
6 & Planting data & 5 & 0 & 0.00 \\
\hline
\end{tabular}

Source: Authors Calculation Based upon similar works of Daramola (1987), Nweke \& Manyoung (2000) and Rahji (2005)

The result tends to suggest that increasing the cassava grower's adoption index score; access to marketing facilities; access to extension facilities and educational programme (such as agricultural shows) will improve income. On the other hand other sources of farm income and access to credit have a negative and significant influence. This implies that the higher of these factors the lower the income. This result thus, suggests that reducing access to credit and focus mainly on cassava enterprise can give higher income.

\section{CONCLUSION}

There is the need for a more widespread adoption of the improved varieties over the old varieties of cassava stem. As empirical findings from this study revealed that, adopters of new improved varieties have higher revenue than non-adopters. Explaining the factor that influence income as a result of adoption, the results indicated that other factors such as sources of farm income apart from income from cassava farm and access to credit have both negative and significant influence at $1 \%$ level. The implication is that increase in these factors will reduce income. To mitigate this the focus should be on the improvement on cassava farm encouraging farmers to use the improved varieties. A priori expectation is that access to credit should increase income; this is because access to credit by cassava growers in the study area revealed 


\section{Journal of Agriculture and Social Research (JASR) Vol. 8, No. 2, 2008}

that the funds were directed to develop or expand other farm enterprises apart from cassava farm enterprise.

Cassava grower's adoption score, access to marketing and extension facilities and education all have positive and significant influence on higher income at different levels. The implication is that increase in these factors will increase income too. As expected, education factor is positive and has significant influence at $1 \%$ level. The implication is that these producers/cassava farmers cannot be sent to school but their adoption process can be enhanced through adult education, aggressive awareness campaigns of new improved varieties/technology and mass mobilization through agricultural information programmes. In this regard, policy to promote an active involvement of extension facilities and services will be very useful. As finding from this study revealed that; access to extension facilities is a likelihood of adoption process and adoption of improved varieties of cassava can improve growers' income.

\section{REFERENCES}

Akoroda, M.O., T. Gebremeski and A. E. Oyinla, 1989. Impact of IITA Cassava varieties On cassava farms in Oyo state, Nigeria, 1976-1985. Tropical Agriculture (Trinidad) 66.2:113-120

Cameron, L. A. 1999. The Importance of learning in the Adoption of High Yielding Variety seeds. America Journal of Agricultural Economic 81.1:83-94.

Daramola, A. G. 1987. Quantitative Analysis of the Adoption of Improved Food Production Technology in Oyo State, Nigeria. Unpublished Ph. D. Thesis, Department of Agricultural Economics, University of Ibadan. xi 215pp.

Ezedinma, C. I. 1989. Impact of some improved practices on Cassava in Anambra State, Nigeria. 2nd Annual General Meeting of collaborative group in Cassava based Cropping systems, held in International Institute of Tropical Agriculture (IITA) Ibadan, Nigeria pages 159-170

Herath, P. H. and H. Takeya, 2003. Factors determining intercropping by rubber small holders in Sri-lanka: A logit Analysis: Agricultural Economic 29:159-168

Idachaba, F. S. 1989. The technology transformation of Agriculture is there hope? Discovery and Innovation 4:28-41.

IFAD/FAO, 2005. The World Cassava Economy, facts, trends and Outlook, Rome, Italy, www.ifad-fao/cassava/Africa-trend/facts htm. August 2006

Ikpi, A. E. and D. Natalie, 1989. Cassava: Lifeline for the Rural Households, Nigeria. Book Builder Inc. Ltd Ibadan pages 1-112.

Manyong, V.M., A. Ikpi, J.K. Olayemi, S.A. Yusuf, B.T. Omonona, V. Okoruwa and F.S. Idachaba, 2005. Agriculture in Nigeria: Identifying opportunities for increased commercialization and investment. IITA, Ibadan, Nigeria xxii $+190 \mathrm{pp}$

Nassimbeni, G. 2001. Technology, Innovation Capacity and the exports attitude of small manufacturing firms. A logit/Tobit Model. Research Policy 30:245-262

Neste, B. L. 1993. Current Trends in Cassava research. Third International and Potential Symposium in Tropical Root crop IITA Ibadan, Nigeria 128-135

Nweke, F. I, B. O. Uguru and A. G. Dixon, 1996. Spread and Performance of Improved Cassava varieties in Nigeria. Collaborative study of cassava in Africa (COSCA) Working Paper, 15: 1-57

Nweke, F. I.and V. Manyong, 2000. Adoption of Improved Cassava varieties in Nigeria COSCA Working Paper 20: 1-106

Nweke, F.I, 2003. The cassava Transformation: Africa Best kept Secret. Dunstan Sc Spencer, edited by John Llynman, Michigan State University Best East Lansing Institute U. S.A 
Journal of Agriculture and Social Research (JASR) Vol. 8, No. 2, 2008

Rahji, M. A. Y. 2005. Determinants of efficiency differentials in Lowland rice production Systems in Niger State, Nigeria, Ibadan Journal of Agricultural Research 1.1:7-17

Tewe, O. O. and M. Bokanga., 2001. Research highlights: Cassava Utilization, Summarized data collected in 2001 for IITA: special paper 205: 1-85 